\title{
Spatial socio-economic heterogeneity of rural areas in the Russian Federation
}

\author{
Irina Turgel ${ }^{1}$, Alexander Pobedin ${ }^{2,}$, and Larissa Bozhko ${ }^{3}$ \\ ${ }^{1}$ Ural Federal University named after the first President of Russia B. N. Yeltsin, 620002, Mira Str. 30, \\ Yekaterinburg, Russia \\ ${ }^{2}$ Ural Institute of Management branch of RANEPA, 620066, $8^{\text {th }}$ of March Str., 66, Yekaterinburg, \\ Russia \\ ${ }^{3}$ Rudny Industrial Institute, 111500, 50 Let Oktyabrya Str. 38, Rudny, Kostanay region, Kazakhstan
}

\begin{abstract}
Implementation of objectives set out in the Strategy for sustainable development of rural territories of the Russian Federation until 2030 requires solving the problems of spatial differentiation among rural territories in different regions of Russia. The article analyzes the level of differentiation using a set of socio-economic indicators of rural areas. The coefficient of variation was used as an indicator of the degree of spatial differentiation. In the course of analysis, the authors identified significant disparities in territorial development for most of the considered indicators, and particularly acute differences were found in economic parameters, including the volume of investment at the expense of the municipal budget. It is revealed that the degree of differentiation between rural territories is influenced not so much by economic development success as by the level of urbanization in the region. The empirical basis of the analysis is research results conducted within the framework of the research project "Improving the policy of state regulation of accelerated clustering of industrial regions" (AP05133531), carried out under grant funding from the Ministry of education and science of the Republic of Kazakhstan.
\end{abstract}

\section{Introduction}

In accordance with the UN sustainable development Agenda approved in 2015, one of the key goals is the need to promote sustainable agricultural development, as well as to reduce socio-economic inequality between different groups of population and between different types of settlements. The Russian Federation has a strategy for sustainable development of rural areas of the Russian Federation until 2030, aimed at improving the level and quality of life in rural areas; there is reduction of both interregional and intraregional differentiation among the principles of state policy indicated in this document. Unfortunately, among the targets defined in the strategy, there are no indicators of the level and extent of spatial disparities. In this regard, development and testing of methodological approaches to the analysis of territorial differentiation of rural territories in Russia is an important task, without

\footnotetext{
*Corresponding author: pobedin-aa@ranepa.ru
} 
which it is impossible to regulate processes of differentiation and successful application of policy tools to smooth out inter-territorial differences.

Traditionally, attention of researchers of territorial development is devoted to cities [1-3], but the problems of rural territories are increasingly reflected in scientific works, including issues of differentiation of rural territories. Among the problems considered by various authors are inefficient use of rural areas [4], coordination of various functions of agricultural areas [5], and quality of life of citizens, environmental problems [7-9], sustainable territorial development [10-12], and human capital development [13]. In this study, the problems of territorial disparities in rural development are considered in the context of the subjects of the Russian Federation in order to assess both the degree of inter-territorial differentiation and identify methodological problems, including those related to the use of indicators presented in Russian statistics.

\section{Materials and methods}

The information base of the study was made up of indicators of socio-economic development of rural territories in the regions of the Russian Federation, published on the official website of the Federal state statistics service (https://rosstat.gov.ru/). There are the following indicators, selected for the analysis: agricultural area, agricultural production, rural population, the share of rural population in total population, agricultural production, the total number of medical institutions, the number involved in youth sports schools, the number of places in collective accommodation facilities, the number of stores, the number of objects of consumer services of the population, investment in fixed capital at the expense of the municipal budget, commissioning of residential homes. Indicators for the study were selected to cover various areas of socio-economic development. For the purpose of comparability of data, some of the indicators were calculated for 10 thousand residents.

The coefficient of variation was used as the main indicator of territorial differentiation; maximum, minimum, and average values were also determined. The statistical package SPSS was used for calculations and analysis. Additionally, individual indicators were ranked; leaders and laggards were determined among the regions.

For Tyumen and Arkhangelsk regions, data was used without taking into account autonomous districts in order to avoid duplication of information (Khanty-Mansi, YamaloNenets and Nenets Autonomous districts were analyzed separately).

\section{Results and discussions}

There are significant differences among regions both in terms of agricultural development and in the level of development of social infrastructure in rural areas in the Russian Federation, (see table 1). The main factors that determine productivity of agricultural production are natural conditions, including the climatic and geographical position. Fifteen most important agricultural regions account for $51 \%$ of all agricultural products produced in the country, and 5 leaders (Krasnodar territory, Belgorod region, Rostov region, Republic of Tatarstan, Voronezh region) produce $25 \%$ of agricultural products. Each region of top five produces more than $4 \%$ of the total Russian agricultural output, and Krasnodar territory, the first of them, produces more than 7\%. Moreover, Krasnodar territory occupies the 12th place in terms of agricultural land area, and Altai, Orenburg, Volgograd, Saratov and Rostov regions are the leaders in this parameter as you can see, only the last region from this list is among the five leaders in agricultural production. In other words, natural conditions that create prerequisites for agricultural production do not guarantee dynamics of its development. Economic success of rural areas is not fully explained by such a factor as the number of 
inhabitants - Krasnodar territory, the Republic of Dagestan, the Republic of Bashkortostan, t Moscow and Rostov regions are the leaders in terms of rural population in the Russian Federation, that is, only two of these regions are also among the top five in terms of agricultural production. There is a significant differentiation between the regions of the Russian Federation (coefficient of variation 1.0, 1.1, and 0.9, respectively), both in terms of agricultural output and in terms of agricultural land area and rural population, and this differentiation is not only due to geographical reasons, but also to differences in investment climate, management efficiency in agriculture, and other factors. It is also interesting that the share of rural population is one of the lowest among the considered indicators, the level of interregional differentiation - the coefficient of variation is only 0.4 , i.e. the ratio of urban and rural population differences between regions are much smaller than three parameters discussed above.

Table 1. Differentiation of subjects of the Russian Federation by individual socio-economic indicators

\begin{tabular}{|l|l|l|l|l|}
\hline $\begin{array}{l}\text { Indicator of socio-economic } \\
\text { development of regions }\end{array}$ & Average & Min & Max & $\begin{array}{l}\text { Variation } \\
\text { coefficient }\end{array}$ \\
\hline $\begin{array}{l}\text { Area of agricultural land, thousand } \\
\text { ha, 2018 }\end{array}$ & 2611,5 & 8,6 & 11004,9 & 1,0 \\
\hline $\begin{array}{l}\text { Volume of agricultural products, } \\
\text { mln. RUB, 2018 }\end{array}$ & 63676,0 & 830,0 & 382468,0 & 1,1 \\
\hline $\begin{array}{l}\text { The rural population, thousands of } \\
\text { people, 2018 }\end{array}$ & 444,7 & 5,6 & 2520,4 & 0,9 \\
\hline $\begin{array}{l}\text { Share of the rural population in the } \\
\text { total number of inhabitants, \%, } \\
\text { 2018 }\end{array}$ & 29,7 & 1,4 & 70,8 & 0,4 \\
\hline $\begin{array}{l}\text { Volume of agricultural products, } \\
\text { million rubles per 10 thousand } \\
\text { inhabitants, 2018 }\end{array}$ & 14002,5 & 3032,7 & 51067,7 & 0,7 \\
\hline $\begin{array}{l}\text { Number of treatment and } \\
\text { prevention organizations, units per } \\
\text { 10,000 inhabitants, 2019 }\end{array}$ & 116,8 & 0,9 & 307,1 & 0,5 \\
\hline $\begin{array}{l}\text { Number of students in children's } \\
\text { and youth sports schools, people } \\
\text { per 10,000 inhabitants, 2019 }\end{array}$ & 1424,4 & 51,7 & 6514,4 & 0,9 \\
\hline $\begin{array}{l}\text { Number of places in collective } \\
\text { accommodation facilities, per } \\
10,000 \text { inhabitants, 2019 }\end{array}$ & 1720,8 & 83,9 & 9196,0 & 0,8 \\
\hline $\begin{array}{l}\text { Number of stores, per 10,000 } \\
\text { inhabitants, 2019 }\end{array}$ & 520,1 & 3,5 & 1023,8 & 0,3 \\
\hline $\begin{array}{l}\text { Number of public service facilities, } \\
\text { units per 10,000 inhabitants, 2019 }\end{array}$ & 108,3 & 2,4 & 349,8 & 0,6 \\
\hline $\begin{array}{l}\text { Investments in the main capital at } \\
\text { the expense of the municipal } \\
\text { budget, thousand rubles per 100 } \\
\text { thousand inhabitants, 2019 }\end{array}$ & 110934,2 & 118,0 & 2673833 & 2,9 \\
\hline $\begin{array}{l}\text { Commissioning of residential } \\
\text { buildings, m of total area per 100 } \\
\text { thousand inhabitants, 2019 }\end{array}$ & 46142,8 & 2614,7 & 189833,6 & 0,7 \\
\hline & & & & \\
\hline
\end{tabular}

For objective comparison of regions, some socio-economic indicators were taken based on 10 thousand inhabitants, but even so, the degree of inter-territorial differences remained very significant. The highest level of differentiation is observed for investments in fixed assets at the expense of the local budget (the coefficient of variation was 2.9). The Yamalo- 
Nenets Autonomous district stands out significantly by this indicator - by 10 thousand people there account for more than 2.5 billion budget investments; in three other subjects of the Russian Federation-the Nenets Autonomous district, Kamchatka territory and the Republic of Sakha (Yakutia), this indicator exceeds 500 million; in other subjects of the Russian Federation - the indicator value is less. Moreover, in 16 regions this figure does not exceed 10 million rubles, and in Chukotka Autonomous district it is 118 thousand rubles, which indicates a huge gap in the budget capabilities of rural administrations in various regions of the Russian Federation, directly affecting development of social infrastructure.

One of the above indicators applies, on the one hand, educational and leisure activities, and on the other hand - healthy population and introducing children to a healthy lifestyle the number of children engaged in sports schools (per 10 thousand people). This indicator also shows significant spatial differentiation - the coefficient of variation reaches a value of 0.9 ; the Republic of Tyva $(6,514)$, the Chechen Republic $(5,653)$, the Republic of Altai $(3,935)$, Yakutia $(3,874)$, and the Yamal-Nenets Autonomous district $(3,868)$ are in top five for this indicator. The minimum value is observed in Tambov (160), Oryol (158), Tula (151), Khabarovsk (113), and Vladimir (52) regions. According to this indicator, there is no connection with the level of economic development of the subjects of the Russian Federation - both Tuva, one of the poorest regions of the country, and the Yamal - Nenets Autonomous district, a rich region specializing in production of hydrocarbons were among the leaders. Partly, variation in this indicator can be explained by the total number of rural learning, as well as the share of rural residents in the subject of the Russian Federation. In any case, there are unequal opportunities for rural children living in different regions of the Russian Federation.

There is high level of differentiation of constituent entities of the Russian Federation on development of hotel infrastructure in rural areas; the variation coefficient on the given indicator is 0.7. Indicator's maximum value of the number of places in collective accommodation facilities per 100 inhabitants fixed for rural areas in the Republic of Altai (9 195 places); Kamchatka Krai, Yaroslavl oblast, Republic of Karelia and Chelyabinsk oblast are also among top five regions-leaders on this parameter. The lowest values of this indicator are observed in Sverdlovsk region and the Nenets Autonomous district, the Republic of Ingushetia, Stavropol territory, and Moscow region. As with the previous parameter, difference here is more likely to be explained by the degree of urbanization in the subject of the Russian Federation than by the level of economic development - if there is a sufficient number of urban areas, accommodation facilities will be located there, and not in rural areas. Accordingly, rural infrastructure development may stagnate, unable to compete with urban areas.

Significant difference is observed in the number of treatment and prevention organizations and in the number of objects of consumer services (coefficients of variation, respectively-0.5 and 0.6). According to the first of these indicators, the highest level is observed in Nenets Autonomous district, Kurgan and Kirov regions, the Republic of Tatarstan and Oryol region. Due to the second they are Nenets Autonomous district, YNAO, Rostov region, Altai territory, and Udmurt Republic. However, it should be noted that a high quantitative value of this indicator does not guarantee a high quality of service to the population in the relevant subjects - additional data should be used here.

Among all the considered indicators, the lowest differentiation between the subjects was revealed by the number of stores per 10 thousand inhabitants - the differentiation indicator was only 0.3 , i.e. shopping infrastructure in rural areas is relatively developed, however, significant differences remain between leaders and laggards in this parameter, the minimum and maximum value of this indicator for the subjects of the Russian Federation differs almost 300 times. 


\section{Conclusion}

1. The analysis showed that the level of differentiation in development of rural areas in the Russian Federation is extremely high; there are significant gaps between the territories. The highest level of differentiation was noted in terms of economic parameters, including investments from the local budget.

2. There are significant differences in the degree of differentiation of rural areas development in the regions of the Russian Federation according to various indicators, and the same region can be both among the leaders and outsiders, depending on the chosen parameter. In this regard, it seems that the use of a single indicator of differentiation, based on mechanical averaging of the level of differentiation for various indicators, without taking into account which factors determine the level of differentiation, will not have practical significance.

3. Economic success of regions does not always determine spatial inequality. It was revealed that the degree of urbanization in the region and the share of rural population affect interregional differentiation. Additional research is required to identify the key factors that determine inter-territorial differences in rural areas development.

4. Quantitative indicators published by Rosstat on development of rural areas largely reflect the presence of certain objects on the territory and availability of certain services, but not the quality of their implementation, for complete assessment of the quality of life in rural areas and the resulting spatial differentiation more complete use of cost parameters is required, reflecting results of the detail of respective organizations.

\section{References}

1. C.R. Lynch, Antipode, 52 (2020)

2. E. Banzhaf, H. Kollai, A. Kindler, Geocarto international, 35 (2020)

3. A.D. Guo, J. Yang, X.M. Xiao, J.H. Xia, C. Jin, X.M. Li, Sustainable cities and society, 53 (2020)

4. Z. Tao, G.H. Jiang, G.Y. Li, D.Y. Zhou, Y.B. Qu, Journal of rural studies, 78 (2020)

5. Y.Y. Yang, W.K. Bao, Y.S. Liu, Ecological indicators, 117 (2002)

6. F. Fang, L.B. Ma, H. Fan, X.L. Che, M.M. Chen, Journal of environmental management, 264 (2020)

7. I. Turgel, L. Bozhko, E. Pracheva, A. Naizabekov. Environmental and Climate Technologies, 23 (2019)

8. I. Turgel, L. Bozhko, E. Ulyanova, A/ Khabdullin. Environmental and Climate Technologies, 23 (2019)

9. L. Jiang, J. Luo, C.Y. Zhang, L.L. Tian, Q.Q. Liu, G.L. Chen, Y. Tian, Isprs international journal of geo-information, 9 (2020)

10. A.S. Gusev, Y.L. Baykin, N.V. Vashukevich, A.A. Belichev, Journal of Environmental Management and Tourism, 11 (2020)

11. M.N. Rudenko, Journal of Advanced Research in Law and Economics, 11 (2020)

12. L.M. Averina, D.V. Sirotin. Economy of Region 16 (2020)

13. S. G. Golovina, I. N. Mikolaychik, L. N. Smirnova, Agrarian Bulletin of the Urals, 8 (2020) 